\title{
Expression, purification and characterization of recombinant human $N$-acetylgalactosamine-6-sulphatase
}

\author{
Julie BIELICKI, Maria FULLER, Xiao-Hui GUO, C. Phillip MORRIS, John J. HOPWOOD* and Donald S. ANSON \\ Lysosomal Diseases Research Unit, Department of Chemical Pathology, Women's and Children's Hospital, 72 King William Road, North Adelaide, South Australia 5006, \\ Australia
}

Full-length cDNA sequences encoding human $N$-acetylgalactosamine-6-sulphatase were stably expressed in Chinese hamster ovary cells under the transcriptional control of the human polypeptide chain elongation factor $1 \alpha$ gene promoter. A clonal cell line overexpressing recombinant $N$-acetylgalactosamine-6-sulphatase to a level of approx. $3 \mathrm{mg} / \mathrm{l}$ of culture medium was isolated. The secreted precursor enzyme was purified to homogeneity by a two-column procedure with an overall yield of
$53 \%$ of the activity. The physical and catalytic parameters of the recombinant enzyme were similar to those of the mature form isolated from liver. On SDS/PAGE and gel filtration, recombinant $N$-acetylgalactosamine-6-sulphatase had a native molecular mass of $58-60 \mathrm{kDa}$. Recombinant $N$-acetylgalactosamine6-sulphatase was endocytosed by mucopolysaccharidosis IVA fibroblasts via the mannose-6-phosphate receptor-mediated pathway and was efficiently localized to lysosomes.

\section{INTRODUCTION}

The mucopolysaccharidoses (MPS) are a subset of a family of disorders known as lysosomal storage diseases. They are characterized by the deficiency of specific enzymes each of which acts as an exohydrolase in the sequential degradation of glycosaminoglycans. In MPS IVA or Morquio A syndrome, the enzyme activity that is lacking is $N$-acetylgalactosamine-6-sulphatase (G6S; EC 3.1.6.4). This enzyme hydrolyses the sulphate ester bonds of GalNAc6S and Gal6S at the non-reducing termini of chondroitin 6-sulphate and keratan sulphate respectively. MPS IVA patients store partially degraded chondroitin 6-sulphate and keratan sulphate in tissues and they also show excessive urinary excretion of these glycosaminoglycans. Morquio A syndrome is inherited as an autosomal recessive trait and is characterized by dwarfism, spondyloepiphysial dysplasia, mild corneal clouding, progressive deafness and joint laxity, especially of the wrist, but, as in MPS VI (Maroteaux-Lamy syndrome), intelligence is normal or minimally reduced, even in severely affected patients [1]. Of the MPS disorders, Morquio A syndrome has a relatively high incidence, and, because there is no involvement of the central nervous system, it would be an ideal candidate for the clinical evaluation of enzyme-replacement therapy. As observed with other MPS disorders, there is a broad spectrum of clinical phenotypes, which implies the occurrence of a number of different mutant alleles at the G6S locus. To date two single-base alterations, one $2 \mathrm{bp}$ deletion and several gross structural gene alterations have been identified [2-4].

G6S has been purified from human liver [5] and placenta [6] and, in common with many other lysosomal enzymes, it appears to be present in extremely low quantities. Enzyme-replacement therapy using enzyme purified from human tissues is not con- sidered feasible for most lysosomal storage diseases. However, the isolation of cDNA clones for lysosomal enzymes coupled with the use of recombinant DNA expression systems has enabled the production of the required amounts of enzyme to treat patients. In this paper we report the expression of full-length G6S cDNA in Chinese hamster ovary (CHO) cells, the purification of the secreted precursor form of G6S and a comparison of its physical and catalytic properties with the mature form of G6S purified from liver. We also demonstrate the mannose 6-phosphate (M-6-P) receptor-mediated enzymic correction of MPS IVA skin fibroblasts.

\section{MATERIALS AND METHODS}

\section{Materlals}

CM-Sepharose, DEAE-Sephacel, PBE94 chromatofocusing medium, Polybuffer 74, high- and low-molecular-mass standard kits for SDS/PAGE and gel chromatography were obtained from Pharmacia (North Ryde, NSW, Australia). TSK G3000SW Ultrapac was purchased from LKB (Bromma, Sweden). The ultrafiltration stirred-cell (model 8200) and Diaflo ultrafiltration membrane YM10 were obtained from Amicon (Danvers, MA, U.S.A.). Dialysis membrane with a 10-12 kDa cut-off was from Union Carbide Corp. (Chicago, IL, U.S.A.). All enzymes for DNA manipulations, DNase, dithiothreitol (DTT), kanamycin and streptomycin were purchased from Boehringer-Mannheim (Dulwich, South Australia, Australia). DNA oligonucleotides were synthesized with a Beckman Oligo 1000 DNA synthesizer. Dulbecco's modified PBS and COON'S Dulbecco's modified Eagle's medium (COON'S/DMEM) were obtained from CSL Ltd. (Melbourne, Vic., Australia). M-6-P, 4-methylumbelliferyl

\footnotetext{
Abbreviations used: GalNAc6S-GIcA-GalitoINAc6S, $O-(-\beta$-D-6-sulpho-2-acetamido-2-deoxygalactosyl)-(1 $\rightarrow 4)$-O- $\beta$-D-glucuronosyl-(1 $\rightarrow 3)$ - $O$ - $\beta$-D-6sulpho-2-acetamido-2-deoxy-[1- $\left.{ }^{-} \mathrm{H}\right]$ galactitol; Gal6S-anM6S, $O-\left(\beta\right.$-D-sulphogalactosyl)- $(1 \rightarrow 4)-2,5$-anhydro-o-[1- $\left.{ }^{3} \mathrm{H}\right]$ mannitol 6 -sulphate; EF-1 $\alpha$, elongation factor-1 $\alpha$; rG6S, recombinant $N$-acetylgalactosamine-6-sulphatase; COON'S/DMEM, COON'S Dulbecco's modified Eagle's medium; rIDS recombinant iduronate-2-sulphatase; $r 4 \mathrm{~S}$; recombinant $\mathrm{N}$-acetylgalactosamine-4-sulphatase; MPS, mucopolysaccharidoses; CHO cells, Chinese hamster ovary cells; M-6-P, mannose 6-phosphate; DTT, dithiothreitol; BME, basal medium Eagle's; FCS, fetal calf serum.

* To whom correspondence should be addressed.
} 
sulphate and BSA were purchased from Sigma (St. Louis, MO, U.S.A.). Basal medium Eagle's (BME), penicillin and glutamine were obtained from Flow Laboratories (Sydney, NSW, Australia), and fetal calf serum (FCS), Ham's F12 nutrient mixture and G418 (Geneticin) were from Gibco (Glen Waverly, Vic., Australia).

\section{DNA manipulation and recombinant plasmids}

All DNA manipulations were carried out using standard techniques [7]. The expression vector pEFNEO [8] has been described previously. The isolation of a G6S cDNA clone has been described [9]. Sequence analysis (results not shown) indicated that this clone contains bases 26-2328 of the sequence described in Figure 1 of Tomatsu et al. [10] and includes the entire $3^{\prime}$ non-coding sequence up to, but not including, the poly(A) tract [9]. This clone is contained within a single EcoRI fragment.

\section{Culture and electroporation of CHO cells}

CHO cells were cultured and electroporated as previously described [11], unless otherwise stated. Calcium phosphate coprecipitation was performed using a standard protocol [7].

\section{Culture of fibroblasts}

Human diploid fibroblasts were established from skin biopsies submitted to this hospital for diagnosis [12]. Cell lines were maintained according to established procedures in BME containing $10 \%(\mathrm{v} / \mathrm{v})$ FCS and antibiotics unless otherwise stated. The MPS IVA skin fibroblasts used in the present study (SF3747) were from a severely affected patient and had low residual G6S activity.

\section{Determination of G6S expression}

Cell lysates prepared by six cycles of freeze-thaw in $20 \mathrm{mM}$ Tris/ $\mathrm{HCl}$ (pH 7.0)/0.25 M NaCl, or media samples, were clarified by microcentrifugation $\left(1200 \mathrm{~g} ; 4^{\circ} \mathrm{C} ; 5 \mathrm{~min}\right)$ and then assayed either directly in assay buffer or after dialysis in $5 \mathrm{mM}$ sodium acetate, $\mathrm{pH}$ 4.0. G6S was assayed using the radiolabelled trisaccharide substrate GalNAc6S-GlcA-GalitolNAc6S [5]. Protein was determined by the method of Lowry et al. [13], with BSA as standard.

\section{Assay of other Iysosomal enzyme activities}

The fluorogenic substrate 4-methylumbelliferyl 2-acetamido-2deoxy- $\beta$-D-glucopyranoside was used to measure $\beta$-hexosaminidase activity [14]. Iduronate-2-sulphatase (IDS) [15], $\alpha$-L-Iduronidase [16] and $N$-acetylgalactosamine-4-sulphatase (4S) [17] were assayed by previously reported procedures.

\section{Endocytosis of rG6S}

The methodology used is essentially that described by Bielicki et al. [8] with the following modifications: SF-3747 fibroblasts were exposed to BME complete medium supplemented with 10 or $1 \mathrm{nmol} / \mathrm{min}$ per ml purified rG6S for $6 \mathrm{~h}$ after which time the medium was changed to fresh medium. The cells were incubated for $24 \mathrm{~h}$ before harvesting. Fractionation on Percoll density gradients was as described by Anson et al. [11]. SF-3747 fibroblasts were exposed to G6S culture medium at a final concentration of $1 \mathrm{nmol} / \mathrm{min}$ per $\mathrm{ml}$ under conditions similar to those described above for endocytosis. The Percoll gradient was centrifuged at $50000 \mathrm{~g}$ for $60 \mathrm{~min}$ at $4{ }^{\circ} \mathrm{C}$ and the resulting gradient was collected in $1 \mathrm{ml}$ fractions.

\section{Large-scale production and characterization of rG6S}

$\mathrm{CHO} / \mathrm{pEFppG6S} \Delta 3^{\prime}$ (clone 16) cells (see the Results and discussion section) were inoculated into two two-layer cell factories (Nunc; $1200 \mathrm{~cm}^{2}$ ) in Ham's F12 containing 5\% (v/v) FCS and antibiotics. Cells were grown to confluency, the medium removed and the cells rinsed three times with PBS and re-fed with $250 \mathrm{ml}$ of COON'S/DMEM without FCS but supplemented with antibiotics. The cells were maintained under the latter conditions for approx. 6 weeks and medium was exchanged and collected every 4 days. The conditioned medium was clarified by centrifugation [2100 $\mathrm{g}(3500 \mathrm{rev} . / \mathrm{min}) ; 4^{\circ} \mathrm{C} ; 10 \mathrm{~min}$ ] and stored at $4{ }^{\circ} \mathrm{C}$. The rG6S was purified from the collected medium by a two-column procedure. Before purification, the conditioned medium was concentrated 10 -fold and then dialysed overnight at $4{ }^{\circ} \mathrm{C}$ against $20 \mathrm{mM}$ Tris/HCl (pH 7.4) containing $10 \%$ (v/v) glycerol, $0.1 \mathrm{mM}$ DTT and $3 \mathrm{mM} \mathrm{NaN}_{3}$ (buffer A). The dialysed medium was applied to a DEAE-Sephacel column $(1.5 \mathrm{~cm} \times 3.0 \mathrm{~cm})$ equilibrated in buffer $A$ (flow rate $2 \mathrm{ml} / \mathrm{min}$ ) and then washed with $40 \mathrm{ml}$ of buffer $A$ before elution of the bound proteins with increasing concentrations of $\mathrm{NaCl}$ in buffer $\mathrm{A}$. Fractions containing G6S activity were pooled, concentrated in an ultrafiltration stirred-cell and the buffer was changed to $50 \mathrm{mM}$ sodium acetate, $\mathrm{pH} 5.0$, containing $10 \%(\mathrm{v} / \mathrm{v})$ glycerol, $0.1 \mathrm{mM}$ DTT and $3 \mathrm{mM} \mathrm{NaN}_{3}$ (buffer $\mathrm{B}$ ). The concentrated and dialysed G6S fractions were applied to a CM-Sepharose column $(1.5 \mathrm{~cm} \times 3.0 \mathrm{~cm})$ equilibrated in buffer $B$ at a flow rate of $2 \mathrm{ml} / \mathrm{min}$. The column was eluted with buffer B which had increasing concentrations of $\mathrm{NaCl}$ from $30 \mathrm{mM}$ to $1 \mathrm{M}$. Fractions with G6S activity were pooled, concentrated and analysed under denaturing and non-denaturing conditions by SDS/PAGE $(10 \%$ acrylamide) [18] to estimate apparent subunit size. Gels were stained with either Coomassie Blue R250 or silver-stained by the method of Merril et al. [19]. Native molecular mass was determined using an FPLC system described elsewhere [5]. Kinetic data $\left(K_{\mathrm{m}}, V_{\max }\right.$ and $\mathrm{pH}$ optima) were obtained using the trisaccharide (GalNAc6S-GlcA-GalitolNAc6S) and disaccharide (Gal6S-anM6S) substrates derived from chondroitin 6-sulphate and keratan sulphate respectively, and inhibition data were obtained using the trisaccharide substrate only. The methodology for deriving these parameters has been described previously [5], the only modifications being that the assay buffer $\mathrm{pH}$ was 4.0 when the trisaccharide substrate was used and $0.2 \mathrm{M}$ sodium formate buffer was used instead of acetate buffer for the reaction with the disaccharide substrate. Kinetic data $\left(K_{\mathrm{m}}, V_{\max }\right.$ and $\mathrm{pH}$ optima) for rG6S, r4S and rIDS using the fluorogenic substrate 4-methylumbelliferyl sulphate was obtained from LineweaverBurk plots with the substrate assayed within a concentration range $0.5-5.0 \mathrm{mM}$. Assay conditions for rG6S activity included $50 \mathrm{mM}$ sodium dimethylglutarate $(\mathrm{pH} 4.66) / \mathrm{BSA}(50 \mu \mathrm{g} / \mathrm{ml})$, and those for rIDS [8] and r4S [11] included $50 \mathrm{mM}$ sodium acetate (pH 5.6)/BSA $(50 \mu \mathrm{g} / \mathrm{ml})$ in a total volume of $100 \mu \mathrm{l}$.

\section{RESULTS AND DISCUSSION}

\section{Construction of G6S expression vectors}

The $E c o$ RI fragment containing the G6S cDNA sequence (see the Materials and methods section) was cloned into the EcoRI site of the plasmid vector pBluescriptIISK (Stratagene) to give pBIG6S. In this clone the $5^{\prime}$ end of the cDNA is adjacent to the HindIII site of the polylinker. The $5^{\prime}$ non-coding sequence of G6S was then replaced with the $5^{\prime}$ non-coding sequence of the rat 


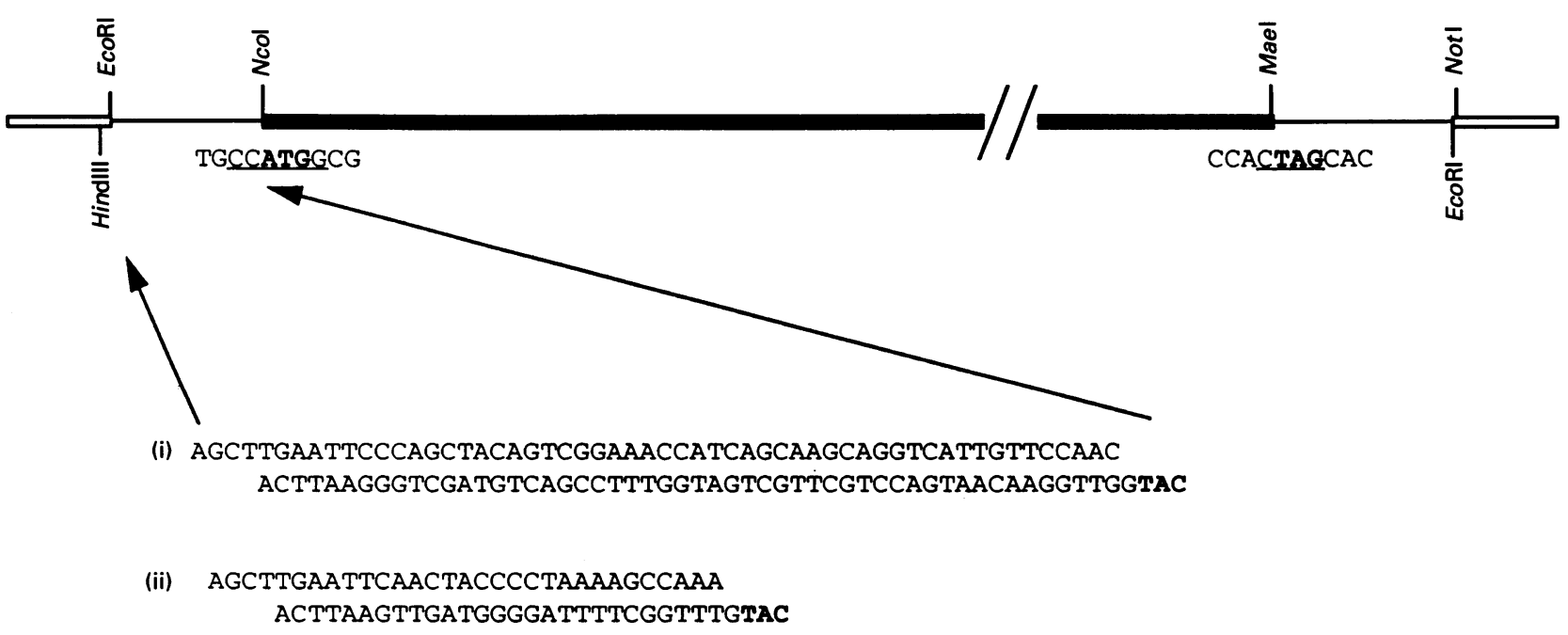

\section{Figure 1 Construction of G6S CDNA}

A line diagram of the G6S CDNA clone cloned into BluescriptlISK is shown. Plasmid sequences are shown as open boxes, G6S non-coding sequences as lines and the G6S-coding sequence as a filled box. The relevant restriction sites are shown with the $\mathrm{Ncol}$ and $\mathrm{Mael}$ sites, and their relationship to the ATG initiation codon and the TAG stop codon (shown in bold) is indicated by underlining. (i) and (ii) show the synthetic preproinsulin and EF-1 $\alpha$ non-coding sequences respectively. For details see the Materials and methods section.

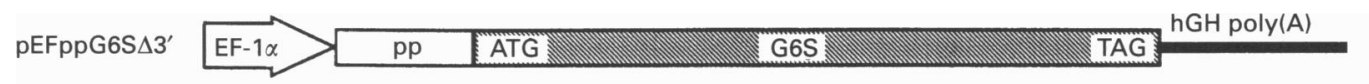

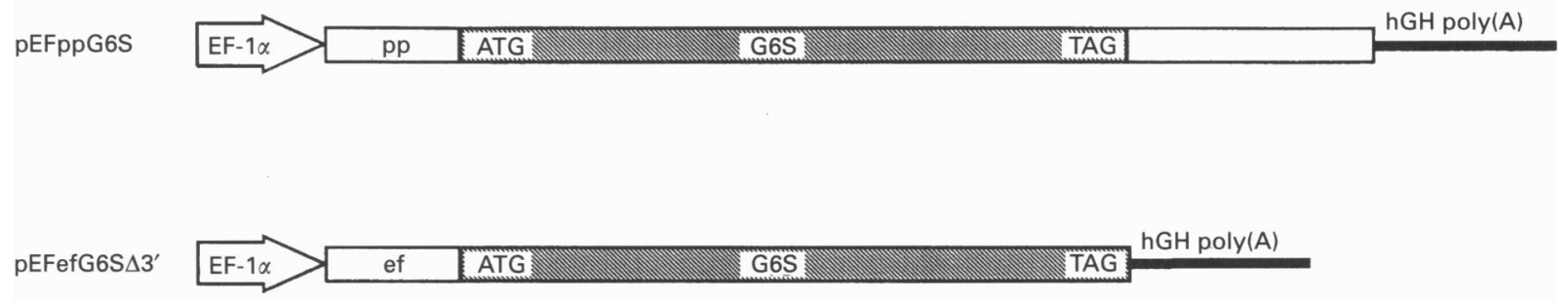

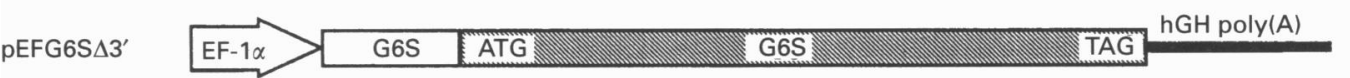

\section{Figure 2 G6S expression cassettes}

The four cassettes used for expression of G6S are shown diagrammatically. Coding sequences are shown as hatched boxes, non-coding sequences as open boxes. EF-1 $\alpha$, EF-1 $\alpha$ gene promoter; $\mathrm{pp}$, preproinsulin $5^{\prime}$ non-coding sequence; ef, human EF-1 $\alpha 5^{\prime}$ non-coding sequence; G6S, sequences from the G6S CDNA; $h G H$ poly(A), the human growth hormone gene polyadenylation signal. The G6S Met initiation codon (ATG) and stop codon (TAG) are shown.

preproinsulin gene as this has previously been shown to ensure efficient expression of cDNAs in mammalian expression systems $[8,11,20,21]$. This was achieved by restriction of pBIG6S with HindIII and NcoI and the subsequent cloning of the required sequence, synthesized as two complementary oligonucleotides, between these two sites (Figure 1) to give pBlppG6S. This plasmid was subsequently modified by deletion of the $3^{\prime}$ noncoding sequence of the G6S cDNA. This was achieved by restriction with MaeI (Figure 1), making this site blunt-ended by incubation with the Klenow fragment of DNA poll in the presence of dNTPs, heat killing the Klenow activity and then restricting with EcoRI to release the cDNA fragment which was purified by gel electrophoresis. The EcoRI-MaeI fragment was cloned into NotI (blunt-ended as described above)/EcoRIrestricted pBluescript to give pBlppG6S $\Delta 3^{\prime}$. pBlppG6S $\Delta 3^{\prime}$ was further modified by replacing the rat preproinsulin $5^{\prime}$ non-coding sequence with the $5^{\prime}$ non-coding sequence of the human polypeptide elongation factor $1 \alpha(\mathrm{EF}-1 \alpha)$ gene, again using complementary oligonucleotides cloned between the HindIII and NcoI sites (Figure 1) to give pBlefG6S $\Delta 3^{\prime}$. The cDNA sequence was 


\section{Table 1 Expression levels of constructs}

The constructs shown were introduced into $\mathrm{CHO}$ cells by electroporation $\left(^{*}\right)$ or calcium phosphate co-precipitation ( $\dagger$ ) and stable transfectants selected by G418 resistance. Mass cultures of transfected cells were assayed for the presence of G6S activity in the cell lysates after dialysis. For details see the Materials and methods section.

\begin{tabular}{ll}
\hline Construct & $\begin{array}{l}\text { G6S activity in cell lysate } \\
\text { (pmol/min per mg) }\end{array}$ \\
\hline No construct & 149.8 \\
pEFppG6S & 75.8 \\
PEFppG6S $\Delta 3^{\prime *}$ & 406.0 \\
PEFefG6S $\Delta 3^{\prime *}$ & 244.0 \\
PEFG6S $\Delta 3^{\prime *}$ & 489.0 \\
pEFG6S $\Delta 3^{\prime} \dagger$ & 693.0
\end{tabular}

then excised from all three of these clones (pBlppG6S, pBlppG6S $\Delta 3^{\prime}$ and pBlefG6S $\Delta 3^{\prime}$ ) with EcoRI and NotI and cloned into EcoRI-NotI-restricted and dephosphorylated pEFNEO, placing the cDNA under the transcriptional control of the human EF-1 $\alpha$ gene promoter, to give pEFppG6S, pEFppG6S $\Delta 3^{\prime}$ and pEFefG6S $\Delta 3^{\prime}$ respectively. A fourth expression construct in which the endogenous $5^{\prime}$ non-coding sequence was retained but which had the $3^{\prime}$ non-coding sequence deleted was also made; this was denoted as pEFG6S $\Delta 3^{\prime}$. A diagrammatic representation of these constructs is shown in Figure 2.

\section{Expression in $\mathrm{CHO}$ cells}

Each of the four expression constructs detailed above were electroporated into $\mathrm{CHO}$ cells, and stably transformed cells were isolated by selection with G418. In addition, the pEFG6S $\Delta 3^{\prime}$ was transfected into $\mathrm{CHO}$ cells by co-precipitation with calcium phosphate. These were expanded as mass cultures, and cell lysates were assayed for G6S activity (Table 1). The highest level of expression was obtained by transfection using the calcium phosphate co-precipitation technique and the pEFG6S $\Delta 3^{\prime}$ construct. The analogous construct in which the $5^{\prime}$ non-coding sequence was replaced with the equivalent sequence from the rat preproinsulin gene (pEFppG6S $\Delta 3^{\prime}$ ) expressed G6S at about $60 \%$ of the level of this construct. We have previously noted with IDS [8] and $\alpha$-L-iduronidase [21] that replacement of the endogenous $5^{\prime}$ non-coding sequence with the rat preproinsulin sequence resulted in enhancement of expression. However, any effect will depend on whether the endogenous sequence is efficient in initiating translation, and in the case of G6S this is presumably so. The use of $5^{\prime}$ non-coding sequences from the EF-1 $\alpha$ gene (designed so that when joined to the fragment used as a promoter, the EF-1 $\alpha 5^{\prime}$ non-coding sequence is re-created in its entirety) did not result in higher levels of expression than that seen with either the G6S or preproinsulin sequence. The one construct that included the $3^{\prime}$ non-coding sequence from the G6S cDNA, pEFppG6S, surprisingly resulted in lower levels of expression of G6S activity than seen in control $\mathrm{CHO}$ cells. The meaning of this observation is unclear; however, it should be noted that the G6S cDNA in this construct contained the endogenous polyadenylation (AATAAA) signal.

The pEFppG6S $\Delta 3^{\prime}$ was used to generate clonal cell lines after electroporation into $\mathrm{CHO}$ cells and a cell line, designated clone 16 , expressing the highest levels of G6S was isolated and used for all subsequent experiments. This construct was used as, although

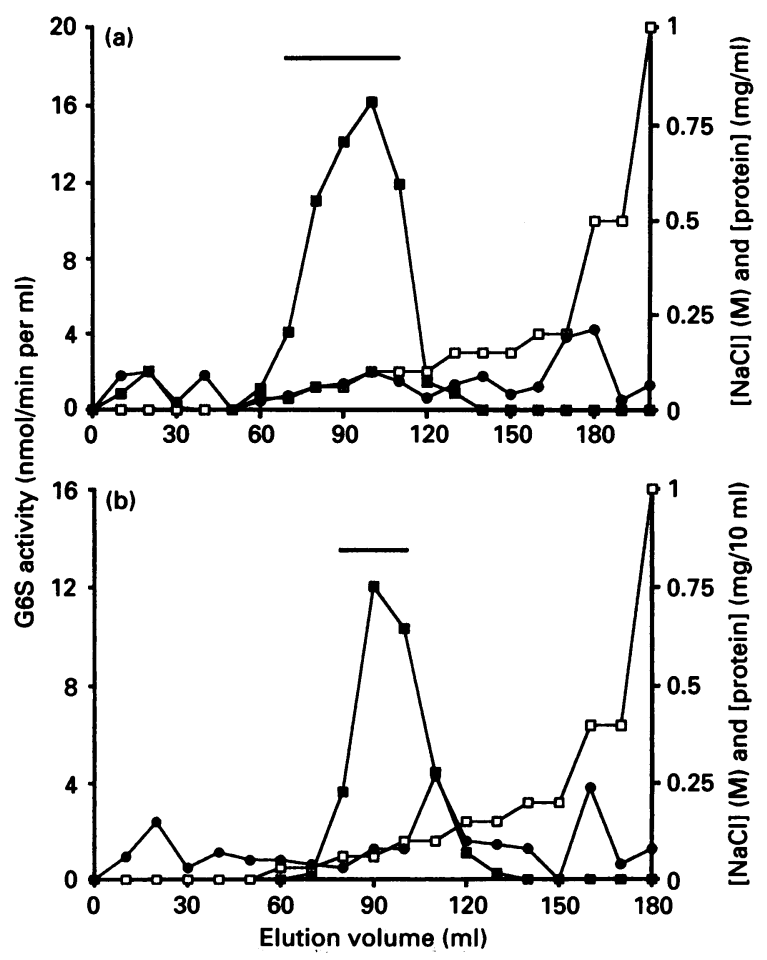

Figure 3 Chromatography of rG6S

For experimental details refer to the Materials and methods section. (a) DEAE-Sephacel and (b) CM-Sepharose chromatography. Fractions indicated were assayed for G6S activity ( $\square$ ), protein (O) and $[\mathrm{NaCl}](\square)$. Fractions were pooled as indicated by the horizontal bars.

it expressed slightly lower levels of enzyme than the best construct, pEFG6S $\Delta 3^{\prime}$, it allowed us to maintain uniformity in the cell lines used for expression of MPS enzymes [8,11,21].

\section{Large-scale production and characterization of rG6S}

Conditioned medium was collected as described in the Materials and methods section. $\mathrm{CHO} / \mathrm{pEFppG} 6 \mathrm{~S} \Delta 3^{\prime}$ (clone 16) cells were not grown in the presence of $\mathrm{NH}_{4} \mathrm{Cl}$ to promote the secretion of precursor [22] as this was found to be unnecessary for efficient secretion of enzyme into the medium and, furthermore, its omission prolonged cell viability and eliminated the need to cycle with and without FCS as described for rIDS expression in Bielicki et al. [8]. Cells were maintained in COON'S/DMEM without FCS for approx. 3 weeks, revitalized with medium plus $2 \%(\mathrm{v} / \mathrm{v})$ FCS for 4 days and then incubated with medium without FCS for another 3 weeks, after which time the cells deteriorated. Medium collected in the manner described had on average $3 \mathrm{mg}$ of $\mathrm{G} 6 \mathrm{~S} / 1$. Application of medium to DEAESephacel required dialysis to remove salts, as the binding to this matrix was relatively weak. Most contaminating proteins were detected in the flow-through and between $150 \mathrm{mM}$ and $1 \mathrm{M} \mathrm{NaCl}$ elutions. G6S activity was eluted between 30 and $100 \mathrm{mM}$ $\mathrm{NaCl}$ (Figure 3a). The increased recovery of enzyme activity $(116 \%)$ may be due to the removal of an inhibitor at this step. The loss of $82 \%$ of the protein that was loaded resulted in a 6.4fold purification. Binding of G6S to CM-Sepharose required dialysis to remove $\mathrm{NaCl}$. $\mathrm{G} 6 \mathrm{~S}$ activity was eluted between 60 and $100 \mathrm{mM} \mathrm{NaCl}$ (Figure 3b) with $53 \%$ yield and 52 -fold purification (Table 2). Native molecular mass of rG6S was estimated 
Table 2 Purification of rG6S from culture medium

For details, see the Materials and methods section.

\begin{tabular}{llllll}
\hline Step & $\begin{array}{l}\text { Total activity } \\
(\mu \mathrm{mol} / \mathrm{min})\end{array}$ & $\begin{array}{l}\text { Total protein } \\
(\mathrm{mg})\end{array}$ & $\begin{array}{l}\text { Specific activity } \\
(\mu \mathrm{mol} / \mathrm{min} \text { per } \mathrm{mg})\end{array}$ & $\begin{array}{l}\text { Total purification } \\
(\text { fold })\end{array}$ & $\begin{array}{l}\text { Recovery } \\
(\%)\end{array}$ \\
\hline Medium & 1.08 & 21.12 & 0.051 & 1 & 100 \\
DEAE-Sephacel chromatography & 1.26 & 3.84 & 0.328 & 6.4 & 116 \\
CM-Sepharose chromatography & 0.58 & 0.22 & 2.680 & 52 & 53
\end{tabular}

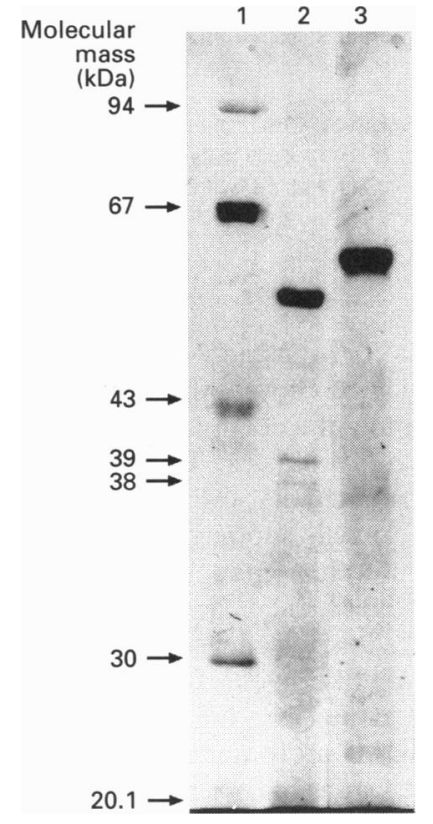

\section{Figure 4 SDS/PAGE of rG6S}

Lanes 1 and 2 are molecular-mass standards and rG6S respectively electrophoresed under reducing conditions $(0.1 \mathrm{mM} \mathrm{DTT})$. The molecular-mass standards (lane 1$)$ and the two minor bands at $39 \mathrm{kDa}$ and $38 \mathrm{kDa}$ (lane 2) are arrowed. Lane 3 is rG6S electrophoresed without DTT. The gel was silver-stained. For details see the Materials and methods section.

on FPLC to be $58 \mathrm{kDa}$ (results not shown). When a sample from the pooled fractions of the CM-Sepharose column was subjected to SDS/PAGE (10\% acrylamide) under reducing conditions, there was a major band at $55-57 \mathrm{kDa}$ and two minor bands (arrowed) at 38 and $39 \mathrm{kDa}$ (Figure 4). The disappearance of the two minor bands and the concomitant increase in intensity of the major protein band $58-60 \mathrm{kDa}$ when a similar sample was run under non-reducing conditions (Figure 4) suggests that the two minor bands may in fact be two differently processed forms of the mature form of G6S which has previously been shown to consist of two disulphide-linked subunits of 39 and $19 \mathrm{kDa}$ [5]. To confirm that the major band on SDS/PAGE was G6S, two identical samples were applied to PAGE under non-reducing conditions by the method of Laemmli [18], but with the modification that SDS was omitted from all buffers. After electrophoresis, both lanes were cut into $2 \mathrm{~mm}$ slices. Each slice from one lane was incubated in assay mix at $37^{\circ} \mathrm{C}$ overnight, while the slices from the other lane were stored in Laemmli sample buffer.
Table 3 Comparison of catalytic properties of recombinant and liver G6S For details, see the Materials and methods section. The results for the liver enzyme are taken from Bielicki and Hopwood [5].

\begin{tabular}{|c|c|c|c|c|}
\hline & $\begin{array}{l}K_{\mathrm{m}} \\
(\mu \mathrm{M})\end{array}$ & $\begin{array}{l}V_{\max } \\
(\mu \mathrm{mol} / \mathrm{min} \\
\text { per } \mathrm{mg})\end{array}$ & $\begin{array}{l}\text { Specific } \\
\text { activity } \\
(\mu \mathrm{mol} / \mathrm{min} \\
\text { per } \mathrm{mg})\end{array}$ & $\begin{array}{l}\mathrm{pH} \\
\text { optima }\end{array}$ \\
\hline \multicolumn{5}{|c|}{ Trisaccharide substrate } \\
\hline Liver G6S & 12 & 1.45 & 1.1 & $3.5-4.0$ \\
\hline rG6S & 15 & 1.99 & 2.1 & 4.0 \\
\hline \multicolumn{5}{|c|}{ Disaccharide substrate } \\
\hline Liver G6S & 50 & 0.09 & 0.07 & $3.5-4.5$ \\
\hline rG6S & 96 & 0.06 & 0.022 & 4.0 \\
\hline
\end{tabular}

When activity was detected, the corresponding slices stored in sample buffer were applied to SDS/PAGE under reducing conditions. The resulting stained gel showed a protein band at 55-57 kDa (results not shown) which corresponded to the major band observed in previous gels. The marginally larger molecular mass of rG6S observed under non-reducing conditions may be the result of different migration properties of the enzyme when in its native conformation or it may be due to experimental variation. On the basis of amino acid sequence derived from the G6S cDNA sequence data, one would predict the unglycosylated enzyme to have a molecular mass of $55 \mathrm{kDa}$ after removal of the 26-amino acid signal peptide [10]. G6S has two potential Nglycosylation sites, only one of which appears to be utilized [6]. This would produce a molecular mass of between 58 and $60 \mathrm{kDa}$ depending on the degree of glycosylation at this site. This is in agreement with the molecular size we observe for the recombinant protein.

G6S has a pl of 5.5-6.5 as determined on PBE94 chromatofocusing medium. In the final step of the purification, the G6S was free of detectable amounts of other lysosomal enzymes including IDS, $\alpha$-L-iduronidase, $4 \mathrm{~S}$ and $\beta$-hexosaminidase (results not shown).

\section{Kinetics of rG6S}

Kinetic data in Table 3 indicate that the liver and the rG6S have similar $K_{\mathrm{m}}, V_{\text {max. }}$, specific activity and $\mathrm{pH}$ optima towards both the di- and tri-saccharide substrates. However, the rate of turnover of the trisaccharide substrate by rG6S was 33-fold greater than that of the disaccharide substrate. This was also 
Table 4 Comparison of effect of various inhibitors on recombinant and liver G6S

For details see the Materials and methods section. n.d., not determined. The results for the liver enzyme are taken from Bielicki and Hopwood [5].

\begin{tabular}{lllll}
\hline & $\mathrm{IC}_{50}$ & & & \\
\cline { 2 - 5 } & $\begin{array}{l}\mathrm{NaCl} \\
(\mathrm{mM})\end{array}$ & $\begin{array}{l}\mathrm{Na}_{2} \mathrm{SO}_{4} \\
(\mu \mathrm{M})\end{array}$ & $\begin{array}{l}\mathrm{Na}_{2} \mathrm{HPO}_{4} \\
(\mu \mathrm{M})\end{array}$ & $\begin{array}{l}\mathrm{Cu}\left(\mathrm{CH}_{3} \mathrm{COO}\right)_{2} \\
(\mu \mathrm{M})\end{array}$ \\
\hline Liver G6S & 24 & 50 & 325 & $\begin{array}{l}\text { n.d. } \\
\text { rG6S }\end{array}$ \\
\hline
\end{tabular}

Table 5 Comparison of the catalytic properties of rG6S, r4S and rIDS towards 4-methylumbelliferyl sulphate

For details see the Materials and methods section.

\begin{tabular}{lccc}
\hline & & $K_{\text {max. }}$ & \\
& $K_{\mathrm{m}}(\mathrm{mM})$ & $(\mu$ mol/min per mg) & $\mathrm{pH}$ optima \\
\hline rG6S & 4.4 & 0.12 & 4.7 \\
IIDS & 12.4 & 0.30 & 5.6 \\
r4S & 4.8 & 17.00 & 5.6 \\
\hline
\end{tabular}

Table 6 Endocytosis of rG6S by MPS IVA fibroblasts

SF-3747 fibroblasts were treated with $10\left(^{*}\right)$ or $1(\dagger) \mathrm{nmol}$ of $\mathrm{rG} 6 \mathrm{~S} / \mathrm{min}$ per $\mathrm{ml}$ in the presence or absence of $5 \mathrm{mM} \mathrm{M-6-P}$ as described in the Materials and methods section. Cell lysates were analysed for G6S activity and total protein. Results are means \pm S.D. for three replicates.

\begin{tabular}{lc}
\hline & $\begin{array}{l}\text { G6S activity } \\
\text { (pmol/min per mg) }\end{array}$ \\
\hline SF-3747 & $2.10 \pm 1.77$ \\
SF-3747 + M-6-P & $1.80+0.18$ \\
SF-3747+rG6S* & $174.5 \pm 19.25$ \\
SF-3747 + rG6S* + M-6-P & $19.3 \pm 2.29$ \\
SF-3747+rG6S $\dagger$ & $50.8 \pm 5.99$ \\
SF-3747 + rG6S + M-6-P & $2.59 \pm 0.75$ \\
\hline
\end{tabular}

observed, though to a lesser degree (16-fold), for the liver enzyme. Inhibition data (Table 4) also showed a marked similarity for the recombinant and liver enzymes with regard to $\mathrm{NaCl}$ and sulphate and phosphate ions. There was also a high degree of sensitivity of rG6S towards inhibition by copper. Results with 4-methylumbelliferyl sulphate (Table 5) indicate that $\mathrm{r} 4 \mathrm{~S}$, which is an arylsulphatase, rapidly catalysed the hydrolysis of this substrate. However, both rG6S and rIDS, which are non-arylsulphatases, nevertheless bound 4-methylumbelliferyl sulphate with similar affinity to the arylsulphatase but the rate of turnover was drastically reduced (138- and 56-fold respectively).

\section{Demonstration of correction of MPS IVA fibroblasts}

Enzymic correction of MPS IVA skin fibroblasts was demonstrated by the endocytosis of rG6S. MPS IVA cells (SF-3747) were cultured in medium supplemented with purified rG6S at 10 and $1 \mathrm{nmol} / \mathrm{min}$ per $\mathrm{ml}$ as described in the Materials and methods

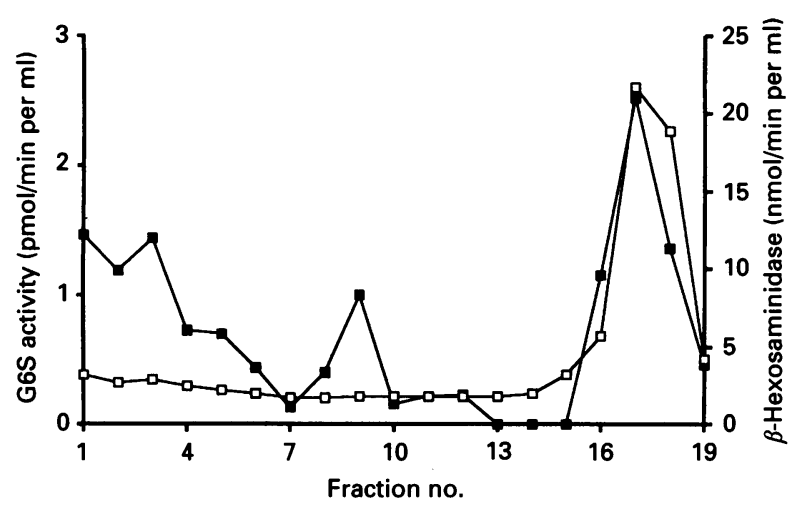

Figure 5 Percoll gradient subcellular fractionation of MPS IVA fibroblasts exposed to rG6S

MPS IVA fibroblasts were exposed to rG6S and cell lysates fractionated on Percoll gradients as described in the Materials and methods section. Fraction 1 is the top of the gradient and fraction 19 the bottom. Fractions were assayed for G6S ( $\square$ ) and $\beta$-hexosaminidase activity (口).

section. After uptake, Morquio A skin fibroblasts had levels of G6S activity that were comparable with or above the normal range (18.2-108 $\mathrm{pmol} / \mathrm{min}$ per $\mathrm{mg}$; V. Muller, unpublished work) observed in control fibroblasts. To show that endocytosis was M-6-P-receptor-mediated, M-6-P at a final concentration of $5 \mathrm{mM}$ was added to cells supplemented with enzyme as above. The results indicate that endocytosis was concentration dependent, but not linear, there being 3.4 times as much uptake with ten times the dose of enzyme (Table 6). The presence of M-6-P abolished uptake by up to $95 \%$, thus confirming that endocytosis was mediated via the M-6-P receptor. Unlike other MPS fibroblasts which store undegraded heparan sulphate and dermatan sulphate fragments, there is no accumulation of stored keratan sulphate or chondroitin 6-sulphate in MPS IVA fibroblasts [1]. The unavailability of MPS IVA chondrocytes that do show storage precluded the demonstration of clearance of stored metabolically ${ }^{35} \mathrm{~S}$-labelled products by endocytosed rG6S.

\section{Localization of endocytosed rG6S}

Postnuclear supernatants from G6S-corrected MPS IVA fibroblasts were fractionated on Percoll density gradients as described in the Materials and methods section. In the corrected MPS IVA cells the rG6S cofractionated with the lysosomal enzyme $\beta$ hexosaminidase in the dense fractions of the gradient (Figure 5). This confirmed its subcellular localization to the lysosome. The G6S activity that was observed at the top of the gradient may reflect enzyme that has adhered to the cell surface and therefore not completely transported to the lysosome, and the activity seen in the middle fractions ( 8 and 9) could be indicative of enzyme in a prelysosomal compartment such as the endosome.

\section{Conclusion}

We have constructed an efficient expression system for human G6S in CHO cells. Active enzyme is secreted into the medium in large amounts and has been purified 52-fold to homogeneity by a simple two-column procedure. The resulting enzyme had a specific activity of $2.7 \mu \mathrm{mol} / \mathrm{min}$ per $\mathrm{mg}$ and had similar properties to the mature liver enzyme with respect to its physical and kinetic parameters as well as to inhibition by various ions. The 
enzyme was effective in correcting the enzyme defect in MPS IVA fibroblasts by rapid endocytosis into lysosomes via the M-6-Preceptor-mediated pathway. The availability of large quantities of purified rG6S makes possible the evaluation of enzymereplacement therapy in Morquio A patients. It could also be used to raise antibodies to assist in the phenotypic characterization of Morquio A patients and furthermore to facilitate a detailed physical analysis, for example, the determination of tertiary structure by X-ray crystallography.

We thank Kathy Nelson for expert assistance with tissue culture and CSL Limited for financial support. This work was supported by a National Health and Medical Research Council of Australia program grant.

\section{REFERENCES}

1 McKusick, V. A. and Neufeld, E. F. (1983) in The Metabolic Basis of Inherited Disease (Stanbury, J. B., Wyngaarden, J. B., Fredrickson, D. S., Goldstein, J. L. and Brown, M. S., eds.), 5th edn., pp. 766-769, McGraw-Hill, New York

2 Fukuda, S., Tomatsu, S., Masue, M. et al. (1992) J. Clin. Invest. 90, 1049-1053

3 Tomatsu, S., Fukuda, S., Ogawa, T. et al. (1994) Hum. Mol. Genet. 3, 1427-1428

4 Tomatsu, S., Fukuda, S., Uchiyama, A. et al. (1994) J. Inher. Metab. Dis. 17, 601-605

5 Bielicki, J. and Hopwood, J. J. (1991) Biochem. J. 279, 515-520
6 Masue, M., Sukegawa, K., Orii, T. and Hashimoto, T. (1991) J. Biochem. (Tokyo) 110, $965-970$

7 Ausubel, F. M., Brent, R., Kingston, R. E. et al. (1989) Current Protocols in Molecular Biology, Wiley Interscience, New York

8 Bielicki, J., Hopwood, J. J., Wilson, P. J. and Anson, D. S. (1993) Biochem. J. 289, 241-246

9 Baker, E., Guo, X.-H., Orsborn, A. M. et al. (1993) Am. J. Hum. Genet. 52, 96-98

10 Tomatsu, S., Fukuda, S., Masue, M. et al. (1991) Biochem. Biophys. Res. Commun. 181, 677-683

11 Anson, D. S., Taylor, J. A., Bielicki, J. et al. (1992) Biochem. J. 284, 789-794

12 Hopwood, J. J., Muller, V., Harrison, J. R. et al. (1982) Med J. Aust. 1, 257-260

13 Lowry, O. H., Rosebrough, N. J., Farr, A. L. and Randall, R. J. (1951) J. Biol. Chem. 193, 265-275

14 Leaback, D. H. and Walker, P. G. (1961) Biochem. J. 78, 151-156

15 Bielicki, J., Freeman, C., Clements, P. R. and Hopwood, J. J. (1990) Biochem. J. 271, $75-86$

16 Clements, P. R., Muller, V. and Hopwood, J. J. (1985) Eur. J. Biochem. 152, 29-34

17 Hopwood, J. J., Elliott, H., Muller, V. J. and Saccone, G. T. P. (1986) Biochem. J. 234, 507-514

18 Laemmli, U. K. (1970) Nature (London) 227, 680-685

19 Merril, C. R., Goldman, D., Sedman, S. A. and Ebert, M. H. (1981) Science 211, $1437-1438$

20 Cullen, B. R. (1988) DNA 7, 645-650

21 Unger, E. G., Durrant, J., Anson, D. S. and Hopwood, J. J. (1994) Biochem. J. 304, 43-49

22 Chang, P. L., Ameen, M., Yu, C. Z. and Kelly, B. M. (1988) Exp. Cell Res. 176, 258-267 